\title{
AS ENTIDADES DELEGATÁRIAS E A COBRANÇA PELO USO DOS RECURSOS HÍDRICOS: A OBRIGATORIEDADE DO REPASSE DOS VALORES ARRECADADOS ÀS ENTIDADES DELEGATÁRIAS E A IMPROBIDADE ADMINISTRATIVA AMBIENTAL
}

\section{THE DELEGATE ENTITIES AND THE CHARGE FOR THE USE OF THE WATER RESOURCES: THE OBLIGATION OF THE TRANSFER OF THE AMOUNTS COLLECTED TO THE DELEGATE ENTITIES AND THE ENVIRONMENTAL ADMINISTRATIVE IMPROBITY}

\author{
Magno Neves Barbosa ${ }^{1}$ \\ Friedrich Wilhelm Herms ${ }^{2}$
}

\begin{abstract}
Resumo
Este estudo propõe o debate sobre a cobrança pelo uso dos recursos hídricos, seu objetivo de dar suporte financeiro ao desenvolvimento de projetos, programas e ações contempladas nos Planos de Bacia Hidrográficas através do debate sobre o repasse obrigatório e sistemático dos valores arrecadados na Bacia Hidrográfica às Agências de Bacia ou, em sua ausência, às entidades delegatárias, e as consequências para o administrador público pelo descumprimento das normas legais.
\end{abstract}

Palavras-chave: Recursos; Hídricos; Gestão; Cobrança; Delegatária; Improbidade; Administrativa; Ambiental.

\section{Abstract}

This study proposes the debate on the charge for the use of water resources, its objective of providing financial support for the development of projects, programs and actions contemplated in the Hydrographic Basin Plans through the debate on mandatory and systematic transfer of amounts collected in the Hydrographic Basin to Water Agencies, or in its absence to the delegate entities, and the consequences for the public administrator for noncompliance with the legal norms.

Keywords: Resources; Water; Management; Collection; Delegate; Improbity; Administrative; Environmental.

\footnotetext{
${ }^{1}$ Doutorando em Direito e Ciências Sociais pela Universidade Nacional de Córdoba (2014) e Mestrando em Gestão e Regulação de Recursos Hídricos pela Universidade do Estado do Rio de Janeiro - UERJ (2016). Diretor Presidente do Instituto Brasileiro de Direito Ambiental - IBDA. Membro da Associação dos Professores de Direito Ambiental do Brasil - APRODAB. Conselheiro no Conselho Municipal de Meio Ambiente da Cidade do Rio de Janeiro - CONSEMAC. Membro efetivo da Câmara Técnica de Direito Ambiental - CTDA, nos Conselhos Estaduais de Meio Ambiente (CONEMA) e de Recursos Hídricos (CERHI) e no Comitê de Bacia Hidrográfica da Baía de Guanabara onde também e membro efetivo da Câmara Técnica de Instrumentos Legais - CTIL. E-mail: magnoneves@gmail.com

2 Doutorado em Química (Química Analítica Inorgânica) pela Pontifícia Universidade Católica do Rio de Janeiro (2001). Consultor ad hoc - Fundo de Apoio à Ciência e Tecnologia da Prefeitura de Vitória, da Fundação de Amparo à Ciência e Tecnologia do Estado de Pernambuco, da Fundação de Apoio à Pesquisa Científica e Tecnológica do Estado de Santa Catarina, da Fundação de Amparo à Pesquisa do Estado de São Paulo, da Fundação Carlos Chagas Filho de Amparo à Pesquisa do Estado do Rio de Janeiro, e do Conselho Nacional de Desenvolvimento Científico e Tecnológico, representante da UERJ na Associação Pró-Gestão das Águas da Bacia Hidrográfica do Rio Paraíba do Sul - AGEVAP, Professor Adjunto V da Universidade do Estado do Rio de Janeiro e representante da ABRH na Câmara Técnica CTCOST do Conselho Nacional de Recursos Hídricos - CNRH. E-mail: fredwh@uerj.br
} 


\section{INTRODUÇÃO}

A água, segundo a legislação vigente sobre recursos hídricos, é um recurso natural limitado, finito, essencial à vida, dotado de valor econômico e de domínio público ${ }^{3,4}$. Sendo que "mais de $12 \%$ do que pode ser utilizado no mundo está no Brasil", entretanto, "o fato é que ela está mal distribuída em relação à densidade demográfica do País" (MILARÉ, 2013, p.520).

Na legislação Nacional o recurso natural "água" é um bem ambiental e, portanto, está sob a égide de um entendimento sistêmico de meio ambiente. A Organização das Nações Unidas ONU reconheceu o direto a água como direto fundamental do ser humano através da Resolução no 64/292 de 28/07/2010 em texto com a seguinte redação: "Reconhece que o direito a água potável e ao saneamento é um direito humano essencial para o pleno aproveitamento da vida e de todos os direitos humanos" 6 .

Michel Prieur argumenta que o direito ao meio ambiente, como direito humano, encontra relativa dificuldade em sua formulação concreta, pois a proteção ambiental concerne não só ao homem, mas a todos os seres vivos e à biosfera. (PRIEUR, 1996, p.59)

De toda sorte, a entrada em vigor da Lei no 9.433/97, que instituiu a Política e o Sistema Nacional dos Recursos Hídricos, constituiu um marco na gestão dos recursos hídricos no Brasil. A Lei das Águas, como é conhecida, fortaleceu o sistema de gestão hídrica através da criação de diversos instrumentos de gerenciamento, como o instrumento de cobrança pelo uso dos Recursos Hídricos, objeto deste trabalho.

A cobrança pelo uso dos recursos hídricos tem previsão Constitucional no inciso XIX de art. 21 Federal e está regulamentada pela Lei Federal no 9.433/97, sendo um instrumento econômico da gestão, tendo por objetivo conferir racionalidade econômica e ambiental ao uso da água, além de buscar os recursos financeiros necessários para implantação e custeio do sistema e

\footnotetext{
3 Parte da doutrina que tem como expoente Paulo Afonso Leme Machado entende que "a água é um dos elementos do meio ambiente. Isto faz com que se aplique à água o Enunciado do art. 225 da CF: "Todos têm direito ao meio ambiente ecologicamente equilibrado, bem de uso comum do povo [...]" esclarecendo "[...] Como vemos, os "rios" sempre foram classificados, do Direito brasileiro, como bens de uso comum do povo, seguindo-se o Direito romano, como se vê nas Institutas de Justiniano." (2014, p.499-500).

${ }^{4} \mathrm{O}$ professor Celso Fiorillo entende a conceituação da água como bem público como sendo uma improbidade uma vez que "tal assertiva padece de inconstitucionalidade, porquanto, conforme demonstrado, a água é um bem tipicamente ambiental, sendo, portanto, de uso comum do povo, e, em conformidade com a Lei 8.079/90 (art.81, parágrafo único, I), bem difuso. Dessa forma, o art. 1ô, I encontrase em total desarmonia com o texto Constitucional, não encontrando neste qualquer suporte de validade" (FIORILLO, 2009, P. 206-207).

${ }^{5}$ Disponível em < http://www.un.org/News/Press/docs/2010/ga10967.dco.htm>, acesso em 19/11/2016.

${ }^{6}$ Texto traduzido pelo professor Paulo Afonso (2014, p.508).
} 
Gerenciamento de Recursos Hídricos bem como a realização dos estudos, programas e projetos e obras contempladas nos Planos de Bacia Hidrográficas.

No presente estudo vamos nos restringir a abordar o objetivo da cobrança que dá suporte financeiro ao desenvolvimento de projetos, programas e ações contempladas nos Planos de Bacia Hidrográficas através do debate sobre o controvertido repasse obrigatório, sistemático e não contingenciável dos valores arrecadados na Bacia Hidrográfica às entidades responsáveis pela aplicação dos recursos arrecadados, isto é, às Agências de Bacia ou, em sua ausência, às entidades delegatárias nos termos das Leis nos 9.433/1997, 9.984/2000 e 10.881/2004 e suas respectivas regulamentações. Também abordaremos as consequências para o administrador público pelo descumprimento das normas legais que envolvem a arrecadação e o repasse dos recursos oriundos da cobrança. Oportuno ainda pontuar que a análise terá como foco central a legislação existente no âmbito federal e que em função da existência de competência constitucional dos Estados sobre os recursos hídricos (26, I CF) existe uma grande variedade de legislações aplicáveis ao tema ora analisado nos diversos Estados da federação.

\section{A COBRANÇA PELO USO DOS RECURSOS HÍDRICOS}

Prevista no inciso III do art. 19 da Lei no 9.433/97, a cobrança pelo uso da água se insere na Política Nacional de Recursos Hídricos como um de seus instrumentos mais importantes, de cunho econômico e objetivando "obter recursos financeiros para o financiamento dos programas e intervenções contemplados nos planos de recursos hídricos"7.

Baseada nos princípios do poluidor-pagador e do usuário-pagador ${ }^{8}$, previstos no inciso VII do art. 4o da Lei no 6.938/19819 é ainda "uma das formas de aplicar o Princípio 16 da Declaração da Conferência das Nações Unidas para o Meio Ambiente e Desenvolvimento de 1992" (MACHADO, 2002, p.79).

\footnotetext{
7 Inciso III do artigo 19 da Lei no 9.433/97.

${ }^{8}$ Não há unanimidade na doutrina ambiental brasileira em relação à diferenciação entre os princípios. Uma linha que tem como expoente Paulo Affonso de Leme Machado (2002, p. 51) entende que o princípio do poluidor pagador está inserido no do usuário pagador. Já outra corrente liderada por Édis Milaré (2013, p. 267-269), que embora reconhecendo proximidades e até certa complementaridade entre os dois princípios, entende-os diferente e de algum modo complementares, pois enquanto o primeiro impõe ao poluidor 0 dever de prevenir e reparar por eventuais danos, o segundo, dá azo à cobrança pela utilização de recursos ambientais, não em caráter punitivo, mas sim, pelo valor que o recurso natural representa de per si ou, ainda, em razão de sua função ecossistêmica.

${ }^{9}$ Art. 40 - A Política Nacional do Meio Ambiente visará: ... VII - à imposição, ao poluidor e ao predador, da obrigação de recuperar e/ou indenizar os danos causados e, ao usuário, da contribuição pela utilização de recursos ambientais com fins econômicos.
} 
O instrumento de cobrança não é uma novidade introduzida pela Lei № 9.433/1997, pois já estava prevista no $\S 2$ ㅇ do art. 36 do Código de Águas de $1934^{10}$, assim descrito: "o uso comum das águas pode ser gratuito ou retribuído, conforme as leis e regulamentos da circunscrição administrativa a que pertencem". Entendo que a novidade, de fato, consistiu em efetivar a cobrança de modo sistêmico com a utilização de outros instrumentos em forma de uma política pública de Estado.

A cobrança pelo uso de recursos hídricos é o mais eficiente dos instrumentos de gestão da política para induzir o usuário da água a uma utilização racional deste recurso ${ }^{11}$. A sua importância reside no fato de atuar sobre as decisões de consumo do agente econômico que tem na água bruta, um dos insumos, às vezes, matéria-prima para a sua produção (GARRIDO, 2000).

Nos termos do art. 19 da Lei no 9.433/97, a cobrança tem o objetivo de (i) reconhecer a água como bem econômico e dar ao usuário uma indicação de seu real valor; (ii) incentivar a racionalização do uso da água; e (iii) obter recursos financeiros para o financiamento dos programas e intervenções contemplados nos planos de recursos hídricos. Não se trata, portanto, de imposto, mas da remuneração pelo uso de bem público, cujo preço ${ }^{12}$ é fixado a partir de pacto entre usuários da água, sociedade civil e poder público no âmbito dos Comitês de Bacia Hidrográfica, a quem cabe pactuar e propor ao respectivo Conselho de Recursos Hídricos os mecanismos e valores de cobrança a serem adotados na sua área de atuação nos termos dos arts. 38 e 39 da Lei no 9.433/97.

Nas palavras de Luis Paulo Sirvinskas, "[...] fazer com que o usuário não a desperdice, utilizando-a de forma racional. É uma forma de o Poder Público obter os recursos necessários para o financiamento dos programas e intervenções contemplados nos planos de recursos hídricos" (SIRVINSKAS, 2002, p.134).

Nos termos do art. 22 da Lei no 9.433/97, valores arrecadados com a cobrança pelo uso de recursos hídricos são aplicados prioritariamente na bacia hidrográfica em que foram gerados, devendo ser utilizados no financiamento de estudos, programas, projetos e obras incluídos nos

\footnotetext{
10 Decreto no 24.643, de 10 de julho de 1934.

11 Embora os valores praticados de PPU - Preço Público Unitário estipulado para a cobrança pelo uso dos recursos hídricos ainda estejam muito aquém de um valor que efetive essa indução.

${ }^{12}$ A cobrança é um preço público, isto é, uma compensação a ser paga pelos usuários de recursos hídricos visando à garantia dos padrões de quantidade, qualidade e regime estabelecidos para corpos d'água das bacias.
}

Revista de Direito da Cidade, vol. 09, no 1. ISSN 2317-7721 pp. 342-365 345 
planos de recursos hídricos ou no pagamento de despesas de implantação e custeio administrativo dos órgãos e entidades integrantes do Sistema Nacional de Gerenciamento de Recursos Hídricos ${ }^{13}$.

Sobre a aplicação dos recursos advindos da cobrança a abalizada doutrina de Paulo Affonso Leme Machado informa que "há uma clara e indubitável vinculação dos recursos financeiros a serem arrecadados pelas Agências de Bacia com o que constar nos programas e projetos dos Planos de Recursos Hídricos" afirmando que "Não há possibilidade de uso discricionário desses recursos financeiros" (MACHADO, 2014, p. 524) e ainda que "se houver necessidade do emprego dos recursos na bacia hidrográfica em que os valores foram gerados, o termo 'prioridade' determina que é nessa bacia, e não noutra, que os valores devem ser aplicados". (BARROS apud MACHADO, 2005, p. 99).

Especificamente sobre o termo prioritariamente previsto no art. 22, Maria Luiza Machado Granziera pondera que "a redação dada ao dispositivo não garante um fator basilar da descentralização da política de recursos hídricos: Que os recursos arrecadados com a cobrança sejam inteiramente aplicados na bacia". E segue pontuando: "A lógica é que os valores são propostos pelo Comitê, assim como o plano de aplicação de recursos. Não há sentido em deixar que haja discricionariedade nessa aplicação, por outro ente que não o comitê. " (GRANZIERA, 2014, p.201).

Contudo, conforme dispõe o art. 6 da Resolução CNRH no 48/2005, para que seja implantada a cobrança em determinada bacia hidrográfica, existem algumas condições prévias que devem ser atendidas antes do início da cobrança. São elas: (i) proposição das acumulações, derivações, captações e lançamentos considerados insignificantes pelo respectivo Comitê de Bacia Hidrográfica e sua aprovação pelo respectivo Conselho de Recursos Hídricos; (ii) processo de regularização de usos de recursos hídricos sujeitos à outorga na respectiva bacia, incluindo o cadastramento dos usuários da bacia hidrográfica; (iii) existência de programa de investimentos definido no plano de recursos hídricos devidamente aprovado; (iv) aprovação, pelo competente Conselho de Recursos Hídricos, da proposta de cobrança, tecnicamente fundamentada, encaminhada pelo respectivo Comitê de Bacia; e (v) implantação da respectiva Agência de Bacia Hidrográfica ou da entidade delegatária do exercício de suas funções.

\footnotetext{
${ }^{13} \mathrm{Na}$ esfera federal os recursos para pagamento de despesas de implantação e custeio administrativo dos órgãos e entidades integrantes do Sistema Nacional de Gerenciamento de Recursos Hídricos prevista no inciso II do art. 22 da Lei no 9.433/97 está limitado a 7,5\% do total arrecadado nos termos do § 10 do artigo 22 acima citado.
}

Revista de Direito da Cidade, vol. 09, no 1. ISSN 2317-7721 pp. 342-365 346 
Apesar do inciso II do art. 6으 da Resolução CNRH no 48/2005 prever apenas a existência de processo de regularização de usos de recursos hídricos sujeitos à outorga para a efetivação da cobrança a doutrina afirma que a cobrança está diretamente vinculada à concessão da outorga. Leciona Paulo Affonso Leme Machado que "a cobrança fica sujeita à outorga, pois não poderá haver cobrança de atividades e obras clandestinas ou cujo uso não tenha sido outorgados" (2014, p.546). Esclarece ainda o autor que "nos casos que tenha havido a suspensão da outorga, no período em que vigorar a suspensão não se efetuará a cobrança" (2014, p. 546). Assim parece razoável o entendimento de que além dos requisitos previstos no art. 6 da Resolução CNRH no 48/2005, deve efetivamente existir outorga válida para que possa ser efetivada a cobrança, estando o inciso II a art. 60 da Resolução CNRH no 48/2005 em desacordo com a legislação vigente.

Duas questões sobre a cobrança previstas na Lei no 9.433/97 ainda devem ser levadas em conta: (i) consoante o art. 20 só serão cobrados àqueles usos que dependem de autorização pelo Poder Público, assim sendo, os usos insignificantes previstos no $\S 1$ o do art. 12 da Lei das Águas e regulados pela Resolução CNRH n. 16/2005, que independem de outorga, não serão objeto de cobrança e (ii) nos termos do $\S 2$ 을 do art. 22 os valores arrecadados poderão ser aplicados a "fundo perdido".

Sobre o tema da dispensa de cobrança:

A legislação estabelece um sistema de justiça social (art. 193 da CF), na medida em que as pessoas menos abastadas não ficarão sujeitas ao pagamento pelo uso da água, posto que seus usos, via de regra, serão tidos como insignificantes [...]. A cobrança, portanto, não afastará a incidência do princípio de acesso universal à água (VIEGAS, 2005, p.108).

Na hipótese de aplicação dos recursos Édis Milaré sustenta que "os valores arrecadados se destinam, ordinariamente, a empréstimo, portanto, com retorno acrescido de juros. Todavia, podem ser aplicados a fundo perdido em projetos benéficos à coletividade". (BARROS apud MILARÉ, 2005, p. 100).

Atendo-nos ao objeto do estudo, sem por óbvio desconsiderar os demais itens do art. 6으 da Resolução CNRH no 48/2005, e ainda observada a eventual possibilidade da existência de outros arranjos institucionais-legais nos Estados em função de suas competências constitucionais sobre os recursos hídricos $(26$, I CF), para que possa ser implantada a cobrança pelo uso dos recursos hídricos é necessário que exista Agência de Bacia ou entidade delegatária o regular exercício de suas funções e outorgas válidas concedidas na bacia. 


\section{AS AGÊNCIAS DE BACIAS E AS ENTIDADES A ELAS EQUIPARADAS (DELEGATÁRIAS)}

Como dispõe o inciso VI do art. 1ำ da Lei no 9.433/97, a gestão dos recursos hídricos deve ser obrigatoriamente descentralizada. Ensina Welington de Barros Pacheco, citando o professor Paulo Affonso Leme Machado, que a referida descentralização da gestão dos recursos hídricos, nada mais é do que a transferência de atribuições tradicionais da União e dos Estados, para os órgãos que foram criados pela Lei no 9.433/97, quais sejam os Comitês de Bacias Hidrográficas e as Agências de Bacia ${ }^{14}$ (art. 33, II e V) (BARROS apud MACHADO, 2005, p.77).

Raymundo José dos Santos Garrido completa este entendimento, ao referir que "o gerenciamento de recursos hídricos deve ser feito nos níveis hierárquicos do governo, ou seja, o que pode ser resolvido na área da bacia hidrográfica não deve ser decidido na capital do Estado ou do país por órgãos mais elevados na hierarquia do serviço público" (2000, p.11).

Nos termos do inciso $\vee$ do art. 33 e do art. 41 da Lei de Águas as Agências de Bacia Hidrográfica integram o Sistema Nacional de Recursos Hídricos, atuando como unidades executivas descentralizadas de apoio ao Comitê de Bacia Hidrográfica e, pelas competências a elas atribuídas por lei, a presunção é de que serão entes dotados de personalidade jurídica própria e de direito público.

Para a criação das Agências de Bacia a Lei das Águas impõe dois requisitos básicos: (i) prévia existência do respectivo Comitê de Bacia Hidrográfica; (ii) viabilidade financeira assegurada pela cobrança do uso dos recursos hídricos em sua área de atuação.

As competências das Agências de Água estão previstas no art. 44 da Lei 9.433/97 e são as seguintes: (i) manter balanço atualizado da disponibilidade de recursos hídricos em sua área de atuação; (ii) manter o cadastro de usuários de recursos hídricos; (iii) efetuar, mediante delegação do outorgante, a cobrança pelo uso de recursos hídricos; (iv) analisar e emitir pareceres sobre os projetos e obras a serem financiados com recursos gerados pela cobrança pelo uso de Recursos Hídricos e encaminhá-los à instituição financeira responsável pela administração desses recursos; (v) acompanhar a administração financeira dos recursos arrecadados com a cobrança pelo uso de recursos hídricos em sua área de atuação; (vi) gerir o Sistema de Informações sobre Recursos Hídricos em sua área de atuação; (vii) celebrar convênios e contratar financiamentos e serviços para a execução de suas competências; (viii) elaborar a sua proposta orçamentária e submetê-la à

\footnotetext{
${ }^{14}$ A Lei no 9.984/200 que criou a ANA traz a expressão "agência de bacia hidrográfica" (§40 do art. 40 e art. 6o da Lei no 9.984/2000). A Lei de Política Nacional de Recursos Hídricos adota o termo "Agência de Água" para descrever a mesma estrutura organizacional.
} 
apreciação do respectivo ou respectivos Comitês de Bacia Hidrográfica; (ix) promover os estudos necessários para a gestão dos recursos hídricos em sua área de atuação; ( $x$ ) elaborar o Plano de Recursos Hídricos para apreciação do respectivo Comitê de Bacia Hidrográfica; (xi) propor ao respectivo ou respectivos Comitês de Bacia Hidrográfica ${ }^{15}$ : a) o enquadramento dos corpos de água nas classes de uso, para encaminhamento ao respectivo Conselho Nacional ou Conselhos Estaduais de Recursos Hídricos, de acordo com o domínio destes; b) os valores a serem cobrados pelo uso de recursos hídricos; c) o plano de aplicação dos recursos arrecadados com a cobrança pelo uso de recursos hídricos; d) o rateio de custo das obras de uso múltiplo, de interesse comum ou coletivo.

O art. 53 da Lei das Águas dispões que: "O Poder Executivo, no prazo de 120 (cento e vinte) dias a partir da publicação desta Lei, encaminhará ao Congresso Nacional projeto de lei dispondo sobre a criação das Agências de Água". O projeto de Lei foi encaminhado somente em 1999, mas tramita até hoje na Câmara dos Deputados ${ }^{16}$.

Em 2004, em função da demora de aprovação do projeto de Lei na Câmara dos Deputados, o governo federal editou a Medida Provisória no 165/ 2004 ${ }^{17}$, convertida, com modificações, na Lei no 10.881/2004, que dispõe sobre os contratos de gestão entre a Agência Nacional de Águas e entidades sem fins lucrativos para a delegação das funções de Agências de Água. Vejamos, por oportuno, trechos da exposição de motivos ${ }^{18}$ da referida Medida Provisória que justificaram a edição da mesma para regulamentação dos contratos de gestão em função das dificuldades enfrentadas pelo sistema nacional de gerenciamento dos recursos hídricos naquele momento, com a ausência das agências de bacia:

Submetemos à consideração de Vossa Excelência proposta [...], com vistas à regulamentação de contrato de gestão entre a Agência Nacional de Águas ANA e as entidades delegatárias das funções de Agência de Água, nos termos do art. 51 da Lei no 9.433[...]

[...]. No art. 53 da mesma Lei está previsto que a criação de Agências de Água depende de lei específica. Tramita já há alguns anos, no Congresso Nacional, o Projeto de Lei no 1616, que visa tratar do assunto.

Ocorre, porém, que a demora na edição de lei específica acarretou situações que exigem um posicionamento imediato no sentido de que as ações de implementação da Política Nacional de Recursos Hídricos, prevista na Lei oo

\footnotetext{
${ }^{15}$ Cabe a observar que uma mesma Agência de Águas e ou entidade delegatária pode ter como área de atuação diversos Comitês de Bacia Hidrográfica como dispõe o artigo 42 da Lei no 9433/97.

16 Projeto de Lei no 1616/1999 que dispõe sobre a gestão administrativa e a organização institucional do Sistema Nacional de Gerenciamento de Recursos Hídricos previsto no inciso XIX do art. 21 da Constituição, e criado pela Lei no 9.433, de 8 de janeiro de 1997, e dá outras providências.

${ }^{17}$ Diário Oficial da União no 111, 11 de junho de 2004. p. 3.

${ }^{18}$ http://www.planalto.gov.br/ccivil_03/_Ato2004-2006/2004/Exm/EMI-5-MMA-CCV-04.htm.
} 
9.433, de 1997, não sofram descontinuidade e coloquem em risco os esforços já desenvolvidos com vistas à gestão adequada do uso da água.

Vários Comitês de Bacia Hidrográfica já foram instalados, [...]. Atualmente a União efetua a cobrança pelo uso de recursos hídricos na Bacia Hidrográfica do Rio Paraíba do Sul, [...], com o respectivo Comitê já devidamente instalado, porém sem contar com a Agência de Água, sua secretaria executiva. Esse fato tem impedido os avanços necessários com vistas ao alcance dos objetivos definidos pela Lei no 9.433, de 1997.

Por outro lado, a Lei no 9.433, de 1997, em seu art. 51, prevê a possibilidade dessa situação ser contornada, até que seja criada a respectiva Agência de Água. [...]

Assim, com vistas a regular a relação do Poder Público com a entidade delegatária das funções de competência das Agências de Água, [...] visam permitir a execução descentralizada de atividades que são de interesses localizados, [...]

Podemos observa que a edição da Medida Provisória no 165/2004 veio devido a necessidade governamental de regular o contrato de gestão, delegando as funções das agências de bacia para entidades da sociedade civil sem fins lucrativos, permitindo a execução descentralizada de atividades de interesses localizados, visando principalmente a implementação da Política Nacional de Recursos Hídricos em um cenário de possível descontinuidade ante a realidade da inexistência das agências de bacia.

O art. 51 da Lei das Águas autoriza o Conselho Nacional de Recursos Hídricos e os Conselhos Estaduais de Recursos Hídricos a delegar a organizações sem fins lucrativos, relacionadas no art. 47 da mesma lei, o exercício de funções de competência das Agências de Água, enquanto esses organismos não estiverem constituídos.

A delegação prevista no art. 51 da Lei das Águas foi regulamentada pela Lei no 10.881/04 que, dispondo sobre o contrato de gestão entre a Agência Nacional de Águas e entidades civis de recursos hídricos previstas no art. 47 da Lei no 9.433/97, definiu instrumento legal específico para a descentralização das funções de Agências de Bacia relativas à gestão de recursos hídricos de rios da União e estabeleceu parâmetros para a relação entre o poder público delegante e a entidade delegatária.

Chamamos atenção para o fato de que a Lei no 10.881/2004 alterou o art. 51 da Lei no 9.433/1997 para ampliar o rol de entidades aptas a receber a delegação dos poderes das Agências de Águas e corrigiu um equívoco jurídico constante da Medida Provisória no 165/2004, que atribuía 
também a Agência Nacional de Águas - ANA competência para delegar poderes uma vez que só o Conselho Nacional de Recursos Hídricos poderia fazer tal delegação ${ }^{19}$.

Sobre o rol de entidades delegatárias proposto pela Medida Provisória no 165/2004, posteriormente convertida na Lei no 10.881/04, o professor Paulo Affonso Leme Machado se manifestou da seguinte forma: "prática irá mostrar se foi uma medida acertada ou um equívoco essa pulverização de modelos de organizações civis. Não se decretou a morte das Agências de Água. Elas poderão ser instituídas a qualquer tempo e, em consequência, encerra-se o contrato de gestão com a entidade delegatária, na sua área de atuação (art. 1ํ, § 2ํ, da Lei no 10.881/2004)." (MACHADO apud KISHI, 2006, p. 163).

No procedimento de delegação para associações sem fins lucrativos"20, os "Conselhos Nacional e Estadual de Recursos Hídricos estão sujeitos às mesmas regras para a criação das Agências de Águas previstas no arts. 48, 43, I e 43, II da Lei 9.433/97, já que essas delegatárias operarão as importantes funções indicadas nos arts. 41 e 44 da Lei de Política Nacional de Recursos Hídricos". (KISHI, 2006, p. 162).

Em função da autonomia constitucional dos entes federativos, cada Estado brasileiro poderá estabelecer, segundo as especificidades locais, a figura jurídica que melhor provier, para a Agência de Água. O Estado de São Paulo, por exemplo, criou através da Lei no 10.020/98, a figura de Agências de Bacia como Fundação de Direito Privado, já o Estado do Rio de Janeiro adotou como ferramenta de gestão do sistema de recursos hídricos as entidades delegatárias que foram regulamentadas através da Lei oㅡ 5639/2010.

Sempre a bom frisar que uma vez instituída a Agência de Água de uma determinada bacia, esta assumirá as competências estabelecidas pelos arts. 41 e 44 da Lei № 9.433/97, encerrando-se, em consequência, o contrato de gestão com a Entidade Delegatária referente àquela.

\footnotetext{
${ }^{19}$ Diz a redação original do art. 51 da Lei no 9.433/1997: "Os consórcios e associações intermunicipais de bacias hidrográficas mencionados no art. 47 poderão receber delegação do Conselho Nacional ou dos Conselhos Estaduais de Recursos Hídricos, por prazo determinado, para o exercício de funções de competência das Agências de Água, enquanto esses organismos não estiverem constituídos". A Lei 10.881/2004 deu a seguinte redação ao art. 51 da Lei no 9.433/1997: "O Conselho Nacional de Recursos Hídricos e os Conselhos Estaduais de Recursos Hídricos poderão delegar a organizações sem fins lucrativos relacionadas no art. 47 desta Lei, por prazo determinado, o exercício de funções de competência das Agências de Água, enquanto esses organismos não estiverem constituídos".

${ }^{20}$ Relacionadas no art. 47 da Lei no 9.433/97.
} 


\section{A DESTINAÇÃO DOS VALORES ARRECADADOS COM A COBRANÇA PELOS USOS DOS RECURSOS HÍDRICOS}

Como já visto, entre outros requisitos, a cobrança só pode ser implantada em uma bacia hidrográfica depois da criação da respectiva Agência de Bacia ou da existência de entidade delegatária do exercício de suas funções, a qual exerce o papel de secretaria executiva do comitê da bacia.

Uma vez implantada, nos termos do inciso IX do art. 4으 da Lei no 9.984/2000, cabe à Agência Nacional de Águas - ANA arrecadar e distribuir e, quando for o caso, aplicar diretamente os valores pagos pelos usuários de recursos hídricos de domínio da União.

Neste ponto a legislação apresenta um aparente conflito de normas posto que a mesma atribuição de arrecadar valores pagos pelos usuários de recursos hídricos de domínio da União, previstas como sendo da Agência Nacional de Águas - ANA, pelo inciso IX do art. 4o da Lei ㄲo 9.984/2000 também é atribuída às agências de bacia nos termos do inciso III do art. 44 da Lei 9.433/97 e não ocorreu revogação expressa do inciso III do art. 44 da Lei 9.433/97 pela Lei no 9.984/2000. Assim, vale ressaltar que, na competência federal e nos termos supra referenciados, existem dois entes executivos do sistema de gestão dos recursos hídricos e responsáveis pela da cobrança e pelo uso dos mesmos, a ANA e as Agências de Bacia.

Entretanto, diante do contexto atual do sistema, onde não existem Agências de Bacia constituídas, o aparente conflito inexiste posto que a cobrança, nos termos da lei, só pode ser feita pela Agência Nacional de Aguas - ANA em função do inciso IX do art. 4o da Lei no 9.984/2000 e da expressa vedação da delegação da cobrança para as entidades delegatárias conforme consta do inciso VI do artigo 2o da Lei no 10.881/2004 21

Nos termos do inciso II do $\S 1$ 을 do art. 17 da Lei no 9.648/98, a parte das receitas arrecadadas decorrentes do pagamento pelo aproveitamento dos potenciais hidrelétricos são aplicadas diretamente pela própria Agência Nacional de Aguas - ANA na implementação da Política Nacional de Recursos Hídricos e do Sistema Nacional de Gerenciamento de Recursos Hídricos.

Entretanto, os valores pagos provenientes das receitas da cobrança pelos usos de recursos hídricos em rios de domínio da União devem ser obrigatoriamente repassados à entidade

\footnotetext{
21 "Art. 20 Os contratos de gestão, elaborados de acordo com as regras estabelecidas nesta Lei, discriminarão as atribuições, direitos, responsabilidades e obrigações das partes signatárias, com o seguinte conteúdo mínimo: [...] VI - a impossibilidade de delegação da competência prevista no inciso III do art. 44 da Lei no 9.433, de 8 de janeiro de 1997.
}

Revista de Direito da Cidade, vol. 09, no 1. ISSN 2317-7721 pp. 342-365 
delegatária que atua nas bacias hidrográficas onde tais receitas foram arrecadadas conforme estabelece do $\S 1$ 어 do art. 40 da Lei no 10.881/2004²2 e ainda é importante frisar que tais valores não podem ser contingenciados nos termos do $\S 3$ 으 do art. 4으 Lei referida lei combinado com $\S 2$ 으 do art. 9ㅇ da Lei Complementar no 101, de 4 de maio de $2000^{23}$.

Tais repasses são realizados mediante contrato de gestão, celebrado entre a Agência Nacional de Aguas - ANA e a entidade delegatária. Esse contrato dispõe sobre atribuições, direitos, responsabilidades e obrigações das partes signatárias, tendo um conteúdo mínimo nos termos do artigo 2 o da Lei ำ 10.881/2004 dos quais destacamos: (i) programa de trabalho proposto, (ii) estipulação de metas a serem atingidas, (iii) prazos de execução, e (iv) prevê critérios de avaliação. A aplicação das receitas, por sua vez, é proposta pela entidade delegatária por meio de um plano de aplicação, o qual é aprovado pelo respectivo Comitê de Bacia Hidrográfica como dispõe a alínea 'c' do inciso Xl, art. 44 c/c art. 51 da Lei no 9.433/97.

Tem-se, portanto, que, acima do debate de quem é a entidade arrecadadora dos recursos provenientes da cobrança pelos usos da água em rios de domínio da União de que tratam os incisos I, III e V do art. 12 da Lei no 9.433/97, as receitas da referida cobrança são garantidas às entidades delegatárias que atuam como secretaria executiva dos comitês das bacias hidrográficas onde foram arrecadadas, aos quais cabe decidir, em última instância, como serão aplicadas tais receitas.

Analisando caso concreto o Plenário do Tribunal de Contas da União no julgamento do processo TC 020.738/2015-324, através do acórdão no 3356-51/15, de relatoria do Ministro André de Carvalho prolatado em 09/12/2015, abordou a questão e se posicionou da seguinte forma sobre o contrato de gestão:

22 Art. 40- Às entidades delegatárias poderão ser destinados recursos orçamentários e o uso de bens públicos necessários ao cumprimento dos contratos de gestão. § 1으ão asseguradas à entidade delegatária as transferências da ANA provenientes das receitas da cobrança pelos usos de recursos hídricos em rios de domínio da União, de que tratam os incisos I, III e V do art. 12 da Lei no 9.433 , de 8 de janeiro de 1997, arrecadadas na respectiva ou respectivas bacias hidrográficas.

${ }^{23}$ Art. 9o Se verificado, ao final de um bimestre, que a realização da receita poderá não comportar o cumprimento das metas de resultado primário ou nominal estabelecidas no Anexo de Metas Fiscais, os Poderes e o Ministério Público promoverão, por ato próprio e nos montantes necessários, nos trinta dias subsequentes, limitação de empenho e movimentação financeira, segundo os critérios fixados pela lei de diretrizes orçamentárias. [...] § 20 Não serão objeto de limitação as despesas que constituam obrigações constitucionais e legais do ente, inclusive aquelas destinadas ao pagamento do serviço da dívida, e as ressalvadas pela lei de diretrizes orçamentárias.

${ }^{24} \mathrm{O}$ processo no TCU tratava de Representação de empresa acerca de irregularidades em coleta de preços conduzida pela Associação Pró-Gestão das Águas da Bacia Hidrográfica do Rio Paraíba do Sul com vistas à elaboração de gestão integrada de resíduos sólidos. 
[...] 40. A partir da edição da Medida Provisória n. 165/2004, posteriormente convertida na Lei Federal no 10.881/2004, a Agevap pôde, por meio do estabelecimento de Contrato de Gestão com a Agência Nacional de Águas ANA, assumir as funções de uma Agência de Bacia, que são, essencialmente, receber os recursos oriundos da cobrança pelo uso da água bruta na bacia e investi-los segundo o plano de investimentos aprovado pelo Comitê da Bacia $[\ldots]$

É importante lembrar que os valores advindos da cobrança pelo uso dos recursos hídricos têm uma finalidade e uma destinação predefinidas. Embora recolhidos pelo erário, são necessariamente repassados e aplicados na consecução dos fins previstos nos arts. 19 e 22 da Lei n. 9.433/97, combinado com art. 4ํ da Lei n. 10.881/04 pelas Agências Delegatárias, sendo que sua aplicação deve respeitar os requisitos previstos na legislação pertinente.

Pontuamos que a Agência Nacional de Águas - ANA, nos últimos anos, vem cumprindo a regra legal e repassando integralmente os valores arrecadados com a cobrança às entidades delegatárias que atuam como secretarias executivas dos comitês das bacias hidrográficas de rios federais onde foram arrecadados os recursos, entretanto, muitos Estados brasileiros não o fazem, dando a tais repasses o mesmo tratamento destinado aos repasses feitos por instrumento de convênio, cuja aplicação está sujeita às restrições previstas na legislação, colocando em risco o sistema de gestão dos recursos hídricos posto que prejudica, ou mesmo inviabiliza, a realização de estudos, programas e projetos e obras contempladas nos Planos de Bacia Hidrográficas.

Ocorre que a transferência de recursos da cobrança pelo uso dos Recursos Hídricos não pode ser equiparada a repasses realizados mediante convênios. Segundo a doutrina abalizada "Convênios administrativos são acordos firmados por entidades públicas de qualquer espécie, ou entre estas e organizações particulares para realização de objetivos de interesse comum dos partícipes. Convênio é acordo, mas não é contrato. No contrato, as partes têm interesses comuns e coincidentes. Por outras palavras: no contrato há sempre duas partes (podendo ter mais de dois signatários); uma, que pretende o objeto do ajuste (a obra, o serviço, etc.); outra, que pretende a contraprestação correspondente (o preço, ou qualquer outra vantagem), diversamente do que ocorre no convênio em que não há partes, mas unicamente partícipes com as mesmas pretensões. Por essa razão, no convênio, a posição jurídica dos signatários é uma só e idêntica para todos, podendo haver, apenas, diversificação na cooperação de cada um, segundo as suas possibilidades para a consecução do objeto comum, desejado por todos. " (MEIRELLES, 1993, p. 354).

Na mesma linha Maria Sylvia Zanella Di Pietro, identifica as mesmas características em relação aos referidos instrumentos, esclarecendo que: 
No contrato, os interesses são opostos e contraditórios, enquanto no convênio são recíprocos [...] os entes conveniados têm objetivos institucionais comuns e se reúnem, por meio de convênio, para alcançá-los: [...] no convênio, os partícipes objetivam a obtenção de um resultado comum; [...] no convênio, verifica-se a mútua colaboração, que pode assumir várias formas, [...]; por isso mesmo, no convênio não se cogita de preço ou remuneração, que constitui cláusula inerente aos contratos; dessa diferença resulta outra: no contrato, o valor pago a título de remuneração passa a integrar o patrimônio da entidade que o recebeu, sendo irrelevante para o repassador a utilização que será feita do mesmo; no convênio, se o conveniado recebe determinado valor, este fica vinculado à utilização prevista no ajuste (2012, p. 284-285).

As receitas decorrentes da cobrança pelo uso da água em rios de domínio da União de que tratam os incisos I, III e V do art. 12 da Lei no 9.433/97 não são recursos orçamentários dos órgãos gestores do sistema, mas apenas são arrecadados e repassados por estes às entidades delegatárias. Assim, não se pode dar a tais repasses o mesmo tratamento destinado aos recursos voluntariamente transferidos às entidades delegatárias, cuja aplicação está sujeita às restrições previstas na legislação que trata de convênios e instrumentos análogos, entretanto, oportuno esclarecer que, além das receitas da cobrança, poderão ser destinados às entidades delegatárias recursos orçamentários e o uso de bens públicos necessários ao cumprimento dos contratos de gestão, conforme estabelece o caput do art. 4ㅇ da Lei no 10.881/2004 e para essas transferências voluntárias a relação jurídica assume caráter análogo a convênio.

O Plenário do Tribunal de Contas da União no julgamento do processo TC 028.088/2013$1^{25}$, através de Acórdão no 0258-04/14 de relatoria do Ministro Walton Alencar Rodrigues prolatado em 12/02/2014, enfrentou a questão e se posicionou nos termos de que a transferência de recursos da cobrança não pode ser equiparada a repasses realizados mediante convênios e, por conseguinte, não pode sofrer as limitações administrativas impostas a aquele instrumento.

Vejamos trecho do acórdão do Tribunal de Consta da União que aborda a questão:

[...] 22. Ou seja, entendeu a Procuradoria-Geral da ANA que seria inviável custear diárias de policiais com receitas provenientes da cobrança pelo uso da água, pois estas são repassadas às entidades delegatárias por meio de contrato de gestão e, como este seria instrumento análogo a convênio, não poderiam ser usadas para pagamento de diárias, passagens e serviços de consultoria ou assistência técnica.

23. Ocorre que, com as devidas vênias, a transferência de recursos da cobrança não pode ser equiparada a repasses realizados mediante convênios. Convênios são acordos de vontades que visam à realização de

\footnotetext{
${ }^{25}$ Que versava sobre consulta do Congresso Nacional sobre a possibilidade de uso de receitas de cobrança pelo uso da água para pagamento de diárias a agentes públicos em fiscalização e monitoramento de recursos hídricos e do meio ambiente.
} 
atividades de interesse comum dos partícipes. Assim, a decisão de aderir ou não ao convênio é livre. Por outro lado, a ANA não dispõe de discricionariedade para se abster de efetuar a transferência dos recursos da cobrança às entidades delegatárias. Ao contrário, esses recursos são a elas legalmente assegurados e sua aplicação é decidida pelo Comitê de Bacia Hidrográfica ${ }^{26}$.

Os recursos arrecadados com a cobrança são transferidos por determinação legal expressa, assim, não dispõe a Agência Nacional de Águas - ANA de discricionariedade para não efetuar a transferência dos recursos às entidades delegatárias. As receitas da cobrança pelo uso da água, em última instância, pertencem aos comitês das bacias hidrográficas em que foram arrecadadas, cabendo a esses órgãos sua destinação através da aprovação do correspondente plano de aplicação e tem seu repasse legalmente assegurado as entidades delegatárias na forma do $§ 1$ do artigo 4으 da Lei 10.881/2004.

Também vale lembrar que tanto a Agência Nacional de Águas - ANA quanto as entidades delegatárias devem fazer a gestão financeira e sua aplicação da forma da Lei, estando a sua gestão sobre a fiscalização dos órgãos de controle, entre eles os tribunais de contas, e o descumprimento por parte dos agentes públicos e privados encarregados da aplicação dos recursos do dever legal previsto na lei com relação aos recursos públicos da cobrança importa em improbidade administrativa ambiental dada a natureza do bem ambiental do qual se revestem os recursos hídricos.

\section{OS RECURSOS ARRECADADOS COM A COBRANÇA PELO USO DOS RECURSOS HÍDRICOS E A IMPROBIDADE ADMINISTRATIVA AMBIENTAL}

O recurso natural "água" é um bem ambiental e, portanto, além de estar sob a égide de um entendimento sistêmico como recurso natural, está inserido em uma série de determinações legais ambientais próprias que se ligam com a gestão de recursos hídricos a exemplo da Lei no 6.938/1981 que no inciso $V$ do art. 3o considera as águas interiores, superficiais e subterrâneas como recursos ambientais.

A natureza e os recursos naturais constituem patrimônio nacional com previsão constitucional no $\S 4$ o do artigo 225, que também estabelece a sua preservação e exploração na forma da lei, dentro de condições que assegurem a preservação do meio ambiente.

Paulo Affonso Leme Machado esclarece que "[...] se o legislador constituinte procedeu à classificação de meio ambiente, e sendo a água um de seus elementos constitutivos, a ela se aplica

${ }^{26}$ Acórdão no 0258-04/14 de relatoria do Ministro Walton Alencar Rodrigues prolatado em 12/02/2014. 
a mesma classificação, [...] fazendo com que se aplique à água o enunciado do caput do art. 225 da CF/88" (MACHADO, 2002, p. 58).

Nas palavras de Emerson Garcia, patrimônio público "é o conjunto de bens e interesses de natureza moral, econômica, estética, artística, histórica ambiental e turística pertencentes ao Poder Público" (2011, p. 204).

No exercício de suas funções, a Administração Pública tem o dever de buscar sempre o interesse público como meio de propiciar o bem-estar social praticando atos previstos em leis. Em questões de proteção e preservação ambiental o agente público não tem qualquer margem de atuação em critérios de conveniência e oportunidade como leciona Hely Lopes Meirelles: "o agente público fica inteiramente preso ao enunciado da lei, em todas as suas especificações" (2006, p. 117).

Luiz Valery Mirra esclarece que:

[...] na maioria das questões relacionadas com a proteção ambiental não há mais, propriamente, liberdade efetiva do administrador na escolha do momento mais conveniente e oportuno para a adoção de medidas específicas de preservação [...]. Nunca é demais repetir que existe, na matéria ora em exame, o dever imposto ao Poder Público de agir para alcançar o fim previsto nessas normas constitucionais e infra-constitucionais. E tal ação não pode ser postergada por razões de oportunidade e conveniência, nem mesmo sob a alegação de contingências de ordem financeira e orçamentária, sobretudo, se dessa atuação depender a cessação da renovação ou do agravamento de danos ambientais". (2004, p. 402).

Já Edis Milaré entende que deve existir um mínimo de discricionariedade técnica por parte do agente público na tomada de decisões asseverando que:

[...] ao levar-se em conta a histórica degradação do meio ambiente promovida em nosso país, em decorrência de ações predatórias resultantes das atividades econômicas e de má gestão pública, é plenamente compreensível e acertada a valorização da atual legislação ambiental. [...], é preciso considerar o ambiente sob um ponto da necessidade que tem a humanidade, [...], de transformar o mundo natural, em consonância com as leis deste último, para prover à sua subsistência e dignificação, sem comprometer a preservação dos recursos ambientais para as presentes e futuras gerações. [...] não se pode separar o elemento formal das normas, puramente literal ou lógico, do seu conteúdo material, dos valores e fins previstos pela legislação ambiental. [...] caso da gestão pública do meio ambiente [...] há que se permitir um mínimo de discricionariedade técnica por parte do agente público na tomada de decisões; uma mera discordância de interpretação, por vezes carente de objetividade, não é suficiente para o ajuizamento de ação de responsabilidade por ato de improbidade. (2013, p.421).

Controvérsias doutrinárias a parte, o fato é que as regras constantes da Lei de Improbidade Administrativa têm importância fundamental para a desejável efetividade das normas de tutela ao 
meio ambiente e, por isso mesmo é correto afirmar que quando há omissão de qualquer representante do Poder Público em matéria ambiental, deve-se busca sua responsabilização imediata, isto porque, as questões ambientais são marcadas de intensa atividade administrativa, concernentes em atos autorizadores ou licenciadores do Poder Público e atos de fiscalização das práticas potencialmente danosas ao meio ambiente, além do implemento de programas voltados à proteção ambiental dos diversos recursos disponíveis, Assim eventual omissão, que não tem por antecedente o exercício da discricionariedade, significa descaso com a coisa pública.

A Lei de Improbidade Administrativa deve ser aplicada de maneira correlacionada com as leis ambientais de forma a observar e obedecer aos princípios que regem o Direito Ambiental, insculpidos pela Constituição Federal. Isso porque, se, por um lado, o Estado é o promotor por excelência da defesa do meio ambiente na sociedade quando elabora e executa políticas públicas ambientais e quando exerce o controle e a fiscalização das atividades potencialmente degradadoras do meio ambiente, por outro lado, ele aparece, também, em muitas circunstâncias, como responsável direto e indireto pela degradação da qualidade ambiental, quando elabora e executa outras políticas públicas - como, por exemplo, as relacionadas ao desenvolvimento econômico e social - e quando se omite no dever que tem de fiscalizar as atividades que causam danos ao meio ambiente e de adotar medidas administrativas necessárias à preservação da qualidade ambiental.

Pazzaglini Filho: afirma que:

[...], o dever jurídico de boa gestão ambiental deve imperar sempre na atuação dos agentes públicos, não thes cabendo, nesse aspecto, qualquer margem de discricionariedade. E a violação deste dever constitucional, além de implicar na reparação do dano ecológico causado, na responsabilidade civil do Estado perante os particulares lesados e na responsabilidade administrativa e, por vezes, penal do agente público responsável pela má gestão ambiental (Lei n. 9.605, de 12.2.1998), pode ensejar a aplicação das sanções estabelecidas na Lei de Improbidade Administrativa (Lei n. 8.429, de 2.6.1992). (2007, p.116).

Discorrendo sobre o tema Édis Milaré, afirma que:

"os princípios e as normas constitucionais determinam que, no regime constitucional democrático brasileiro, a probidade é a conduta exigível da Administração, em todos os seus setores e [...] campos de atuação". Segue o autor esclarecendo que "a partir da Constituição Federal de 1988, positivouse o combate à corrupção administrativa, pois, até então, a legislação cuidava apenas de um tipo de improbidade: o enriquecimento ilícito. Sob a nova ordem constitucional, e com a edição da Lei n. 8.429/1992, alargou-se a esfera de proteção do patrimônio público. O bem jurídico tutelado não é mais apenas o erário, mas também a própria probidade administrativa. Com isso, o controle se ampliou para abranger qualquer prática de corrupção que 
tenha ou não lesado concretamente o erário; destarte, não só o bem público material é tutelado, mas também a gestão ética e eficiente do patrimônio público. [...]. Desse controle não escapa a Administração Pública ambiental, que está vinculada a um corpo de instrumentos legais no intuito principal de promover a preservação da qualidade de vida e o desenvolvimento sustentável." Contudo, é o próprio doutrinador esclarece que a Lei de Improbidade Administrativa "alcança o administrador desonesto, não o inábil", e que "a improbidade [...] está diretamente vinculada ao aspecto da conduta do agente público, afrontando o padrão jurídico da moral, da boafé, da honestidade e da lealdade", destacando que, "o STJ assim já decidiu no julgamento do Resp. 213.994-MG (Relator Ministro Garcia Vieira, DJU de 27.9.1999)". (2013, p. 369).

Sobre a questão da existência de dolo ou culpa para a prática de ato improbo podemos citar julgado ocorrido em 2012 no Agravo Regimental no Recurso Especial no 1.253.667/MG de lavra do Ministro Humberto Martins, onde a jurisprudência da corte é refirmada ${ }^{27}$ e do qual destacamos o seguinte trecho:

É firme a jurisprudência do STJ, inclusive de sua Corte Especial, no sentido de que 'não se pode confundir improbidade com simples ilegalidade. A improbidade é ilegalidade tipificada e qualificada pelo elemento subjetivo da conduta do agente. Por isso mesmo, a jurisprudência do STJ considera indispensável, para a caracterização de improbidade, que a conduta do agente seja dolosa, para a tipificação das condutas descritas nos artigos 9o e 11 da Lei 8.429/92, ou pelo menos eivada de culpa grave, nas do artigo 10

Os atos de improbidade foram agrupados em três categorias pela Lei de Improbidade Administrativa: (i) atos que importam em enriquecimento ilícito, previstos no artigo 9o; (ii) atos que causam prejuízo ao erário, estabelecidos no artigo 10; e (iii) atos de improbidade que atentam contra os princípios da Administração Pública, na forma do artigo 11.

Vale destacar ser entendimento pacificado na doutrina e na jurisprudência que as condutas previstas nos artigos 9 a 11 da Lei de Improbidade são exemplificativas, não contemplando todas as práticas de improbidades possíveis, as quais deverão ser enquadradas nas fórmulas genéricas

${ }^{27}$ ADMINISTRATIVO. LEI DE IMPROBIDADE ADMINISTRATIVA. LEI N. 8.429/92, ART. 11. AUSÊNCIA DE DOLO OU CULPA CONSIGNADA NO ACÓRDÃO RECORRIDO. NÃO CARACTERIZAÇÃO DO ATO DE IMPROBIDADE.

1. É firme a jurisprudência do STJ, inclusive de sua Corte Especial, no sentido de que 'não se pode confundir improbidade com simples ilegalidade. A improbidade é ilegalidade tipificada e qualificada pelo elemento subjetivo da conduta do agente. Por isso mesmo, a jurisprudência do STJ considera indispensável, para a caracterização de improbidade, que a conduta do agente seja dolosa, para a tipificação das condutas descritas nos artigos 9o e 11 da Lei 8.429/92, ou pelo menos eivada de culpa grave, nas do artigo 10.' (AIA 30/AM, Corte Especial, DJe de 27/09/2011). (Grifo nosso)

2. A Corte de origem, ao consignar que o enquadramento do agente público no art. 11 'não exigiria a comprovação de dolo ou culpa por parte do gestor público, ou mesmo a existência de prejuízo ao erário', contrariou o entendimento desta Corte.

3. Como o agravante não trouxe argumento capaz de infirmar a decisão que deseja ver modificada, esta deve

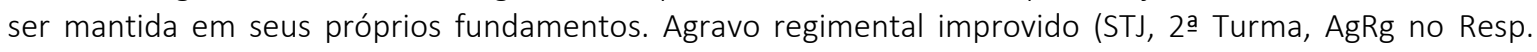
1253667/MG, relator Ministro Humberto Martins, DJe 11/05/12). 
traçadas pelos respectivos artigos. "Assim, pode-se encontrar correspondência do ato em um dos incisos dos artigos citados, facilitando o enquadramento da situação fática à descrição legal, mas pode ocorrer que a situação fática não se amolde aos incisos, o que não significa atipicidade da conduta ímproba" (TURRA SOBRANE, 2005, p. 50).

Corroborando com as premissas acima apontadas, a Lei Federal no 10.257/01, que trata do Estatuto da Cidade é um exemplo de norma que contempla ato de improbidade administrativa decorrente da inércia do Prefeito Municipal. O art. 52 preconiza que: "Sem prejuízo da punição de outros agentes públicos envolvidos e da aplicação de outras sanções cabíveis, o Prefeito incorre em improbidade administrativa, nos termos da Lei no 8.429, de 2 de junho de 1992, quando: [...]VI impedir ou deixar de garantir os requisitos contidos nos incisos I a III do $\S 4$ o do art. 40 desta Lei; VII - deixar de tomar as providências necessárias para garantir a observância do disposto no § 3 o do art. 40 e no art. 50 desta Lei".

Também é importante pontuar que a responsabilidade por improbidade administrativa é subjetiva, Alexandre Moraes aponta que ela "consagrou a responsabilidade subjetiva do servidor público, exigindo o dolo nas três espécies de atos de improbidade (arts. 9o, 10 e 11) e permitindo, em uma única espécie - art. 10 -, também a responsabilidade a título de culpa" (2003, p. 362).

Reforçando este posicionamento Maria Sylvia Zanella Di Pietro, afirma que "O enquadramento da lei de improbidade exige culpa ou dolo por parte do sujeito ativo. Mesmo quando algum ato ilegal seja praticado, é preciso verificar se houve culpa ou dolo, se houve um mínimo de má-fé que revele realmente a presença de um comportamento desonesto[...]". (2002, p.688).

Em se tratando os bens ambientais de riqueza incomensurável, enquadram-se os atos de improbidade dos quais resulte qualquer forma de degradação ao patrimônio ambiental nas sanções previstas na Lei 8.429/92, que no seu artigo 50 impõe o integral ressarcimento do dano lesão ao patrimônio público por ação ou omissão, dolosa ou culposa, do agente ou de terceiros.

Marino Pazzaglini Filho leciona que:

"Os órgãos e entidades públicas têm o poder-dever de atuar na tutela ambiental para 'assegurar a efetividade do direito ao meio ambiente ecologicamente equilibrado' (art. 225, § 1ㅇda CF). Essa atuação obrigatória e prioritária decorre da norma constitucional, em especial do princípio da prevenção e precaução, que é impositivo, vinculante e coercitivo. [...] 0 dispositivo constitucional utiliza a expressão 'assegurar a efetividade desse direito', o que realça, na área do meio ambiente, o princípio constitucional da eficiência (art. 37 da CF), que deve ser observado pela Administração Pública em geral e sempre nortear a conduta dos agentes públicos 
encarregados do controle ambiental. Portanto, na defesa e preservação do meio ambiente ecologicamente equilibrado para as presentes e futuras gerações, não basta aos organismos e aos agentes públicos comportamentos ativos e omissivos neutros, insuficientes para reparar, prevenir e precaver os danos ambientais. É mister que organismos e agentes públicos executem as tarefas de sua responsabilidade, direcionadas sempre à reparação ou à proteção mais adequada, mais eficaz possível, dos recursos ambientais: a atmosfera, as águas interiores, superficiais e subterrâneas, os estuários, o mar territorial, o solo, o subsolo, os elementos da biosfera, a fauna e a flora (inciso $V$ da Lei no 6.938, de 31-8-81, com a redação dada pela Lei no 7.804 de 18-7-89). Por conseguinte, os agentes públicos, no exercício da tutela do meio ambiente, em face do comando específico das normas ambientais de prevenção, precaução e efetividade (art. 205, caput e $\S 1$ 으, da CF) e do princípio universal da eficiência (art. 37, caput da CF), têm o dever jurídico de adotar e executar as medidas mais eficazes e produtivas para a satisfação do meio ambiente ecologicamente equilibrado. Enfim, o dever jurídico de boa gestão ambiental deve imperar sempre na atuação dos agentes públicos, não Ihes cabendo, nesse aspecto, qualquer margem de discricionariedade. A violação desse dever constitucional, além de implicar a reparação do dano ecológico causado, a responsabilidade civil do Estado perante os particulares lesados e a responsabilidade administrativa e, por vezes, penal do agente público responsável pela má gestão ambiental (Lei no 9.605 de 12-2-1998), pode ensejar a aplicação de sanções estabelecidas na Lei de Improbidade Administrativa" (2000, p. 55-56).

Assim, pelo acima exposto podemos concluir que tanto os servidores públicos vinculados às entidades gestoras de recursos hídricos quanto os diretores e funcionários das entidades delegatárias ${ }^{28}$ quando - dentro de suas atribuições - arrecadam, repassam e aplicam os recursos oriundos da cobrança que tem por finalidade o gerenciamento e a preservação do recurso natural/bem ambiental "água" devem adotar sempre praticar atos capazes e eficazes objetivando o interesse público e a preservação ambiental. Logo, se dessa forma não agem, responderão por improbidade administrativa.

${ }^{28}$ Com a Emenda Constitucional no 18/1998, o art. 37 passou a englobar quatro espécies de agentes públicos, prestadores de serviço à Administração Pública: os agentes políticos, os servidores públicos, os militares e os particulares em colaboração com o Poder Público. Os particulares em colaboração com o Poder Público são pessoas físicas que não possuem vínculo empregatício com o Estado; embora prestem serviço a este, não são remunerados diretamente pelos cofres públicos, situação na qual se enquadram os diretores e funcionários das entidades delegatárias. Segundo Maria Sylvia Zanella Di Pietro, dentre as possibilidades existentes de colaboração, há como espécie, a delegação do Poder Público, em que os particulares atuam em seu próprio nome, sem vínculo empregatício e sob a fiscalização do Poder Público concedente, como os notários, registradores e empregados de empresas concessionárias e permissionárias de serviço público (2012, p. 589). 


\section{CONSIDERAÇÕES FINAIS}

Através da interpretação da legislação vigente e da análise da doutrina jurídico ambiental pátria afeta ao tema, demonstramos que o repasse dos valores arrecadados na Bacia Hidrográfica às entidades delegatárias é obrigatório, sistemático e não passível de contingenciamento e que as mesmas são as instâncias responsáveis pela aplicação destes recursos, que tem sua aplicação guiada por parâmetros rígidos e objetivos, mas de construção coletiva e ainda que a aplicação de outra interpretação importa em discricionariedade inaceitável no âmbito da gestão dos Recursos Hídricos

A Constituição Federal brasileira de 1988 atribuiu especial importância à ética e à competência no trato da coisa pública, estabelecendo, de forma inovadora, a observância em todos os níveis da administração pública da probidade na prática dos atos administrativos, e assim, sendo a água um bem público que deve ser preservado e a aplicação correta dos recursos uma ferramenta para a preservação deste bem, sua aplicação de forma diversa do que determinada na legislação vigente (inclusive quanto ao repasse dos recursos) importa em improbidade administrativa relacionada com a má administração do patrimônio público e com a responsabilidade de impedir a degradação ambiental. Os agentes públicos ou pessoas a eles equiparados, (funcionários das entidades delegatárias) que assim procederem estarão praticando ato de improbidade administrativa ambiental que deve ser punido na forma da Lei no 8.429/92.

\section{REFERÊNCIAS BIBLIOGRÁFICAS}

ANTUNES, Paulo Bessa. Direito ambiental. 9. ed. Rio de Janeiro: Lumen Juris, 2006.

BARROS, Wellington Pacheco. A Água na Visão do Direito. Porto Alegre: Tribunal de Justiça do Rio Grande do Sul, 2005.

BRASIL. Agência Nacional de Águas. Bacia Hidrográfica do Rio Paraíba do Sul: Arrecadação por usuários - Exercício de 2011. Brasília, Agência Nacional de Águas. Cobrança pelo Uso da água, 2011. Disponível <http://arquivos.ana.gov.br/institucional/sag/CobrancaUso/Arrecadacao/2011/PorUsuarioPBS_201 1.pdf>. Acesso em 15 de novembro de 2016.

Agência Nacional de Águas. Cobrança pelo Uso de Recursos Hídricos na Bacia Hidrográfica do rio Paraíba do Sul: Relatório. Brasília: Agência Nacional de Águas, 2010.

Conselho Nacional de Recursos Hídricos - Resolução CNRH no 48 de 21 de março de 2005. Estabelece critérios gerais para a cobrança pelo uso dos recursos hídricos. Disponível em $<$ http://www.cnrh.gov.br/index.php?option=com_content\&view=article\&id=48>. Acesso em 20 de novembro de 2016. 
Constituição da República Federativa do Brasil. Disponível em: <https://www.planalto.gov.br/ccivil_03/constituicao/constituicao.htm>. Acesso em 20 de novembro de 2016.

Decreto Federal no 24.643, de 10 de julho de 1934. Decreta o Código de Águas. Disponível em:<https://www.planalto.gov.br/ccivil_03/decreto/d24643.htm>. Acesso em 20 de novembro de 2016.

Lei Federal no 10.881 de 9 de julho de 2004. Dispõe sobre os contratos de gestão entre a Agência Nacional de Águas e entidades delegatárias das funções de Agências de Águas relativas à gestão de recursos hídricos de domínio da União e dá outras providências. Disponível em: <http://www.planalto.gov.br/ccivil_03/_ato2004-2006/2004/lei//10.881.htm>. Acesso em 20 de novembro de 2016.

Lei Federal no 6.938 de 31 de agosto de 1981. Dispõe sobre a Política Nacional do Meio Ambiente, seus fins e mecanismos de formulação e aplicação, e dá outras providências. Disponível em: <http://www.planalto.gov.br/ccivil_03/LEIS/L6938.htm>. Acesso em 20 de novembro de 2016.

Lei Federal no 9.433/97 de 8 de janeiro de 1997. Institui a Política Nacional de Recursos Hídricos, cria o Sistema Nacional de Gerenciamento de Recursos Hídricos, regulamenta o inciso XIX do art. 21 da Constituição Federal, e altera o art. 10 da Lei no 8.001, de 13 de março de 1990, que modificou a Lei no 7.990, de 28 de dezembro de 1989. Disponível em: <http://www.planalto.gov.br/ccivil_03/leis/L9433.htm>. Acesso em 20 de novembro de 2016.

Lei Federal no 9.648, de 27 de maio de 1998. Altera dispositivos das Leis no 3.890-A, de 25 de abril de 1961, no 8.666, de 21 de junho de 1993, no 8.987, de 13 de fevereiro de 1995, no 9.074, de 7 de julho de 1995, no 9.427, de 26 de dezembro de 1996, e autoriza o Poder Executivo a promover a reestruturação da Centrais Elétricas Brasileiras - ELETROBRÁS e de suas subsidiárias e dá outras providências. Disponível em: <http://www.planalto.gov.br/ccivil_03/leis/L9648cons.htm>. Acesso em 20 de novembro de 2016.

Lei Federal no 9.984 de 17 de julho de 2001. Dispõe sobre a criação da Agência Nacional de Águas - ANA, entidade federal de implementação da Política Nacional de Recursos Hídricos e de coordenação do Sistema Nacional de Gerenciamento de Recursos Hídricos, e dá outras providências. Disponível em: <http://www.planalto.gov.br/ccivil_03/leis/L9984.htm>. Acesso em 20 de novembro de 2016.

Medida Provisória no 165 de 11 de fevereiro 2004. Dispõe sobre o contrato de gestão entre a Agência Nacional de Águas e as entidades delegatárias das funções de Agência de Água, nos termos do art. 51 da Lei no 9.433, de 8 de janeiro de 1997, e dá outras providências. Disponível em: <http://www.planalto.gov.br/ccivil_03/_Ato2004-2006/2004/Mpv/165.htm>. Acesso em 20 de novembro de 2016.

Superior Tribunal de Justiça. Agravo regimental (AgRg) no Recurso Especial (Resp) no 1.253.667/MG. Relator Ministro Humberto Martins. Segunda Turma, julgado em 24/04/2012, DJe $11 / 05 / 2012$

Disponível em: $<$ https://ww2.stj.jus.br/processo/revista/documento/mediado/?componente=ITA\&sequencial=114 $1598 \&$ num_registro $=201100849507 \&$ data $=20120511 \&$ formato=PDF $>$. Acesso em 15 de novembro de 2016.

Tribunal de Contas da União. Acórdão no 0258-04/14 no Processo TC no 028.088/2013-1, Relator Ministro Walton Alencar Rodrigues. Disponível em: <http://www.tcu.gov.br/Consultas/Juris/Docs/judoc/Acord/20140219/AC_0258_04_14_P.doc>. Acesso em 22 de novembro de 2016.

Tribunal de Contas da União. Acórdão no 3356-51/15 no Processo TC no 020.738/2015. Relator Ministro André de Carvalho. Disponível em: 
$<$ https://contas.tcu.gov.br/sagas/SvIVisualizarRelVotoAcRtf?codFiltro=SAGAS-SESSAOENCERRADA\&seOcultaPagina=S\&item0=543061>. Acesso em 22 de novembro de 2016.

FIORILLO, Celso Antonio Pacheco. Curso de direito Ambiental brasileiro, 10 eds. rev., atual. E amp. São Paulo: Saraiva, 2009.

FREITAS, Vladimir Passos de (org.). Águas, Aspectos Jurídicos e Ambientais. 3a Edição - 2a reimpressão. Curitiba: Juruá. 2011.

GARCIA, E.; ALVES, R. P. Improbidade Administrativa. 6. ed. Rio de Janeiro: Lumen Juris, 2011. v. 1.

GARRIDO. R. Introdução. In: THAME. A. C. M. (organizador). A cobrança pelo uso da água. São Paulo: IQUAL, 2000.

GRANZIERA, Maria Luiza Machado. Direito das Águas: Disciplina Jurídica das Águas Doces. 4a Ed. São Paulo: Atlas 2014.

KISHI, Sandra Akemi Shimada. Gestão integrada, participativa e descentralizada das águas, Revista brasileira de direito ambiental v. 2, no 6, abr./jun., 2006, São Paulo: Ed. Fiuza, 2006.

MACHADO, Paulo Afonso Leme. A Substituição das Agências de Água, in Revista de Interesse Público, Porto Alegre: Notadez, ano 5, v. 26, jul-ago, 2004.

MACHADO, Paulo Afonso Leme. Direito ambiental brasileiro. 22a rev., ampl. e atual. São Paulo. Editora Malheiros, 2014.

MACHADO, Paulo Afonso Leme. Recursos Hídricos. Direito Brasileiro e Internacional, São Paulo: Malheiros, 2002.

MEIRELLES, Hely Lopes. Direito Administrativo Brasileiro, 18ą. ed., São Paulo: Malheiros, 1993.

MILLARÉ, Édis. Direito do Ambiente. 8a Ed. rev. atual. e reform., São Paulo: Revista dos Tribunais, 2013.

MIRRA, Álvaro Luiz Valery Mirra. Ação civil pública e a reparação do dano ao meio ambiente. 2a ed. São Paulo: Juarez de Oliveira, 2004.

MORAES. Alexandre. Direito Constitucional. 1a Ed. São Paulo: Atlas, 2008.

ONU - Organização das Nações Unidas. Resolução no 64/292 de 28 de julho de 2010. Aprovou Resolução A/RES/64/292. Disponível em <http://www.un.org/press/en/2010/ga10967.doc.htm>. Acesso em 19 de novembro de 2016.

PAZZAGLINI FILHO, Marino. Princípios Constitucionais Reguladores da Administração Pública. São Paulo: Atlas, 2000.

PELLACANI, Christian Rodrigo. Poluição das Águas Doces superficiais e Responsabilidade Civil. 1a Edição, 7ạ Reimpressão. Curitiba: Juruá. 2012. 
PIETRO, Maria Sylvia Zanella Di. Direito Administrativo. 14ạ. ed. São Paulo: Atlas, 2002.

PRIEUR, Michel. Droit de L'Environnement. Paris: Dalloz, 1996.

SÃO PAULO. Lei Estadual no 10.020 de 3 de julho de 1998. Autoriza o Poder Executivo a participar da constituição de Fundações Agências de Bacias Hidrográficas dirigidas aos corpos de água superficiais e subterrâneos de domínio do Estado de São Paulo e dá outras providências correlatas. Disponível em: <http://www.al.sp.gov.br/repositorio/legislacao/lei/1998/lei-1008323.09.1998.html >. Acesso em 22 de novembro de 2016.

SIRVINSKAS, Luís Paulo. Manual de direito ambiental. 13. ed. São Paulo: Saraiva, 2015.

TURRA SOBRANE, Sérgio. A Lei de improbidade administrativa e sua utilização para a proteção das florestas brasileiras. Revista do Direito Ambiental. № 16, São Paulo: RT, 2005.

VIEGAS, Eduardo Coral. Visão Jurídica da Água, 1a Ed., Porto Alegre: Livraria do Advogado, 2005.

Trabalho enviado em 16 de dezembro de 2016.

Aceito em 20 de janeiro de 2017. 